\title{
A NEW COMBINATION IN BULBINE
}

Hermann in his Catalogue of Plants growing in the Leiden Botanic Garden in 1687, described and figured on p. $466, t .467$, a plant that came from the Cape of Good Hope belonging to a species that is still common in the S.W. Cape. He gave it the phrase name Ornithogalum africanum luteum odoratum foliis cepaceus radice tuberosa. From the good description and plate it is obvious that it is a Bulbine, for he describes the barbate filaments and in this genus there is a section that produces a large rounded tuberous base. This led Hermann and later Houttuyn and Miller to retain it in the bulbiferous genus Ornithogalum.

Miller in 1768 bestowed the binomial Ornithogalum tuberosum on Hermann's plant in his Gardener's Dictionary, ed. 8 , No. 10 , repeating Hermann's description and information that it grows naturally on the dry rocks at the Cape of Good Hope.

Jacquin in his Icones Plantarum Rariorum 2, t .405 (1795) and Coll. 5: 83 (1797) painted and described this species under the name Anthericum pugioniforme. Link in his Enumeratio, 1: 329 (1821) transferred it to Bulbine, viz. B. pugioniformis (Jacq.) Link. Baker included it under the latter name in the Flora Capensis 6: 363 (1896), but misapplied the name Ornithogalum tuberosum Mill., placing $O$. polyphyllum Jacq. as a synomym under it on p. 506.

As Ornithogalum tuberosum has not been transferred to Bulbine the combination is now effected.

Bulbine tuberosa (Mill.) Oberm., comb. nov.

Ornithogalum tuberosum Mill., Gard. Dict. ed. 8, No. 10 (1768). Type: Hermann, Cat. Lugd. t.467.

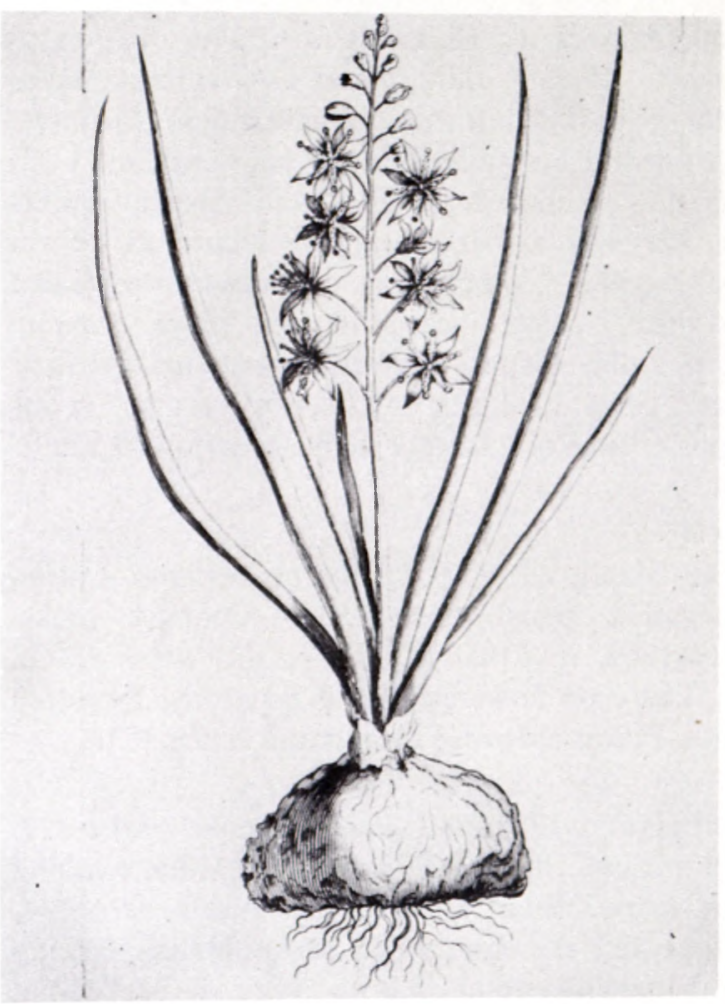

FIG. 12.-Iconotype of Bulbina tuberosa (Mill.) Oberm., t. 467 in Hermann, Cat. Lugdb. (1768). 